\title{
MYC wt Allele
}

National Cancer Institute

\section{Source}

National Cancer Institute. MYC wt Allele. NCI Thesaurus. Code C53086.

Human MYC wild-type allele is located in the vicinity of $8 \mathrm{q} 24.21$ and is approximately $5 \mathrm{~kb}$ in length. This allele, which encodes myc proto-oncogene protein, plays a role in the regulation of transcription by RNA polymerase II. Burkitt's lymphoma is associated with at least three translocations, $\mathrm{t}(2 ; 8)(\mathrm{p} 12 ; \mathrm{q} 24), \mathrm{t}(8 ; 14)(\mathrm{q} 24 ; \mathrm{q} 32)$ and $\mathrm{t}(8 ; 22)(\mathrm{q} 24 ; \mathrm{q} 11)$ which fuse the gene to the promoter site for either the immunog lobin heavy or light chain genes. In a variety of other tumors the gene is expressed aberrantly. 